\title{
Towards a Marxist Biocentric Climate Justice Theory of African Cinema
}

\author{
Towards a Marxist Biocentric Climate Justice Theory of African Cinema \\ Abstract
}

African cinema after colonialism examined issues on politics, polemics of gender, morality, historical reconstruction, resuscitation of cultural values and so on. All of the above were the pivot on which postcolonial African films were hinged. The rise of environmental consciousness in the 1980s through the 1990s championed by William Rueckert, Cheryll Glotfelty, Harold Fromm and Adrian Ivakhiv's Biocentrism created spaces for the African filmmaker's search for climate justice with the medium of his art. It is pertinent to note that traditional African societies were ecocentric precursory to their encounter with the West. This Biocentric nature of indigenous Africa, the dislocation of the continent by capitalism and the effect of climate change on the continent made it easy for the African creative artist and filmmaker to venture into the ecological film enterprise. Laden in some of these films are the socioeconomic, political and environmental thoughts of Karl Marx, Ali Mazrui, Omafume Onoge and William Ruekert. Despite the above, there abounds a dearth of holistic environmental theories that bridges the economic, political and environmental Humanities. To this end, I propound a Marxist Biocentric Climate Justice theory which encapsulates political, economic and environmental processes. I adopt content analysis method to situate Christoffer Guldbrandsen's Why Poverty? Stealing Africa (2012) and Orlando Von Einsiedel's Virunga (2014) in the context of the theory being propounded.

Keywords

Environmentalism, Marxism, Climate Justice, Biocentrism and African Cinema

\section{Introduction}

In his seminal discourse, Orientalism, Edward Said argues that during the colonial enterprise, the land was the first commodity to be colonized. Land is an integral element of the postcolonial discourse. The colonization of the people of Africa of course began with the colonized's ceding of their land to the imperialists. The 
land tenure system in Wa Thiong'o's Kenya, Alan Paton's South Africa, Kenneth Kaunda's Zambia and Robert Mugabe's Zimbabwe tells the imperative of land in the colonial process. The natural resource on the continent which attracted the imperialist was housed in the land. The African fertile soil, the gold in South Africa and Ghana, the crude oil in Nigeria and the Copper in Zambia were all locked on the African land. Unfortunately, however, this land, a subset of nature has been exploited and marginalized. "It is evident that nature has been positioned as the Other, a concept that has been closely associated with postcolonialism"1. The marginalization of nature has played an influential role in the shifting of ecocentric ideology to anthropocentric attitudes².

This othering of the environment is fully captured by Wole Soyinka, the Nigerian literary icon, in his play, The Lion and the Jewel. In this play, Lakunle, obviously influenced by the culture of the Western mode of production, talks to Sidi, the village belle, about his intention to cut down the trees in Ilujinle and build night clubs. He valourizes Lagos, a cosmopolitan city in Nigeria, where more factories are being built. The setting up of these factories comes to bear after deforestation exercise. Also, most of these factories are injurious to man and the environment since the attention of these factories is the profit their private owners would make from them. Herein lie the connection of capitalism and environmental degradation. Max Weber's definition of capitalism comes to bear here. He establishes that capitalism is the pursuit of profit and forever renewed profit by means of continuous, rational, capitalistic enterprise ${ }^{3}$. Brett Clark and John Foster, professors in global political economies contend that the problem of the destruction of nature is the problem of capitalism ${ }^{4}$. This stems from the fact that individual growth and material gain are the primary concern of capitalism ${ }^{5}$. Capitalism is hinged on individual profit making, irrespective of the harm such profiteering does to man and the environment. This is the core of John Foster and Brett Clark's ecological revolution, "processes aimed at making peace with the planet"6.

Capitalism does not only colonize the human and non-human underprivileged, it also pitches the duo (underprivileged human and nature) against one another. By the non-human, I refer to the environment made up of the biosphere and

${ }^{1}$ R. Baruah, Coloniality of Humans and the Ecology: An Eco-critical Reading of Shubhangi Swarup's Latitudes of Longing, [in:] S. Kochar, M.A. Khan (eds.), Environmental Postcolonialism: A Literary Response, New York 2021.

2 Ibidem.

${ }^{3}$ M. Weber, The Protestant Ethic and the Spirit of Capitalism. New York 1958.

${ }^{4}$ B.Clark, J. Foster, Marx's Ecology in the $21^{\text {st }}$ Century, "World Review of Economy" 2010, (2).

${ }^{5}$ S. Duggal, Colonialism, Capitalism, and Nature: A Study of Alex Haley's Roots and Ngũgĩ Wa Thiong'o's Petals of Blood, [in:] S. Kochar, M.A. Khan (eds.), Environmental Postcolonialism: A Literary Response, New York 2021.

${ }^{6}$ B. Clark, J. Foster, Marx's Ecology..., op. cit. 
lithosphere. Paradigmatically, the Bourgeoisie uses the proletariat to pull down trees that serve as raw materials for industries. The energy of the proletariat comes to play in the destruction process of nature. Thus, the exploitation of nature and dehumanization of human beings are completely intertwined. Colonizers violated the protective boundaries of nature and then ill-treated Africans who were living peacefully in that pastoral environment ${ }^{7}$.

Although Rob Nixon in Environmentalism and Postcolonialism decried that the "African Humanities has been slow to absorb the spirit of ecocriticism as the West", especially in the academic space, it is pertinent to note unknown to him the African especially Nigerian Humanities have a couple of ecocritics such as Lere Adeyemi, AbdulRasheed Adeoye and Taiye Adeola, who are of the opinion that the advancement in capitalist processes is responsible for environmental degradation. Their position corroborates Brett Clark and John Foster's (2010) argument that capitalism is the problem of climate change, and as such, the only solution to environmental degradation, is ecological revolution. This notwithstanding, eocritics have always hinged their description and analysis of the environmental question on a single approach-political, economic, etc. In other words, there abounds a dearth of holistic environmental theories that bridges the economic, political and environmental Humanities. Against this backdrop, I propound a Marxist Biocentric Climate Justice theory which encapsulates political, economic and environmental processes. I adopt content analysis method to situate Christoffer Guldbrandsen's Why Poverty? Stealing Africa (2012) and Orlando Von Einsiedel's Virunga (2014) in the context of the theory being propounded.

\section{Appropriating a Marxist Biocentric Climate Justice Theory}

My aim at appropriating a Marxist Biocentric Climate Justice theory is to create a single theory, out of the three concepts that have already been appropriated by different theorists - Karl Marx and Adrian Ivakhiv, with which the economic, political and environmental Humanities could be analyzed. The three concepts, Marxism, Biocentrism and Climate Justice are revolutionary. They are transformative processes, tailored toward radical transformative change and counter approaches to anthropocentrism. It is pertinent to have an understanding of the three concepts in their individual contexts, investigate their linkage. Biocentrism is an offspring of the larger environmental school, ecocriticism, championed by William Rueckert, Cheryll Glotfelty and Harold Fromm. The Biocentric model

\footnotetext{
7 S. Duggal, Colonialism, Capitalism..., op. cit.

${ }^{8}$ R. Nixon, Environmentalism and Postcolonialism, [in:] T. Olaniyan, A. Quayson (eds.), African Literature: An Anthology of Criticism and Theory, Oxford, United Kingdom 2007.
} 
of ecocriticism is otherwise called deep ecology. Deep ecology involves the acknowledged unity of man and all the creatures and the environment around him?. It advocates the equality of species. Deep ecology contends that all creatures have their intrinsic values and as such, no one creature must dominate the other. This approach recommends a shift from humancentrism to Biocentrism. This means a transition from the culture of human dominance into a tradition of cooperation between man and nature. The tenets of Biocentrism are:

1. Awareness of the more than human in the work of art;

2. The environment as a character;

3. Equality of all species in the art work;

4. The protection of the environment;

5. The radical struggle against anthropocentrism;

6. Art depicts human beings are tied in a web of connections with nature;

7. Nature's intrinsic value beyond the utility it provides humans in the work of art;

8. The subjugation of capitalism by socialism in the work of art ${ }^{10}$.

Climate Justice is broader than one could imagine. Its inquiry is not only in the ambit of the reduction of climate change, it also dovetails into the politics of social inclusion. Environmental degradation is premised on the politics of silencing and marginalization. Those who bear the brunt of gas flaring and climate change are silenced. They are gag from speaking and placed at the margin. As an indigene of the Niger Delta region of Nigeria, I observe numerous oil spillages, gas flaring and deforestation by capitalist driven industries (especially transnational firms). Unfortunately, the inhabitants of this geographical area who suffer from the brunt of the environmental crises do not have a say about how the condition of the environment could be improved on. Thus, climate justice investigates how all and sundry can participate in the decision making process of how the environment can be mitigated. Climate Justice is participatory, democratic and it empowers the Bourgeoisie and the proletariat. It uses the medium of inclusivity to empower the people and the environment.

The above reveals that Climate Justice intersects with Marxism. Karl Marx, a Law student turned Philosopher, examined the economic systems especially in Europe of the $18^{\text {th }}$ and $19^{\text {th }}$ century and noticed an economic dialectical material divide of the people and system. Oluwaponmile Adetunji, in Marxist Secular Humanist and Christian Approaches to Moral Education clearly summarizes Marx's ideology thus:

In a primitive society, the relations of production are those of cooperation. But at a stage in the history of man, certain members of society acquired control over the productive forces. This action according to Marx, enabled the minority to live by the labour of the majority.

${ }^{9}$ Ecocriticism - A Theoretical Perspective, Ecological Concerns in Selected Indian Fiction, 2018.

${ }^{10}$ A. Ivakhiv, Green Film Criticism and its Futures, "Interdisciplinary Studies in Literature and Environment" 2008, 15 (2). 
And this scheme takes the place of the fall of man. The inclination of men to take advantage of one another was a corruption introduced into history by the private ownership of the means of production. When production forces were altered, productive relations followed suit. These relations, therefore, became antagonistic classes ${ }^{11}$.

It becomes obvious in the above quotation, that those who control the production process which Marx terms Substructure, will do all it takes to retain control of it and facilitate an upsurge of this control. To have a firm grip of the sub, production needs to increase. The influx of production therefore leads to the need to get access to more raw materials. In Nigeria for example, the capitalist process and focus on the oil industry has led to the proliferation of more transnational oil companies such as Shell BP, Chevron, Rainoil, Agip, Conoil, Oando, Exxon Mobil and many others. This has also led to the expansion of the search for more oil which has wrecked more havoc to the lithosphere and biosphere of the Niger Delta. The havoc wrecked on the proletariat by the bourgeoisie with the latter's control of the mode of production is what led to Marx's prophecy of a revolution-a revolt by the proletariat on the bourgeoisie, in order to stabilize the economic process. To this end, Biocentrism, Climate Justice and Marxism are therefore interwoven and revolutionary. From the foregoing, I establish the tenets of Marxist Biocentric Climate Justice theory viz:

1. Celebration of socialism over capitalism;

2. The victory of Biocentrism over Anthropocentrism;

3. The complimentarity of man and nature;

4. Art for economic and environmental mitigation;

5. Environmental transformation through peaceful and radical paradigms;

6. Valourization of the environment over its destruction.

I use the above tenets to examine Christoffer Guldbrandsen's Why Poverty? Stealing Africa (2012) and Orlando Von Einsiedel's Virunga (2014) in the context of the theory understudy.

\section{Marxist Biocentric Climate Justice in Guldbrandsen's Why Poverty? Stealing Africa and Einsiedel's Virunga}

Guldbrandsen's Why Poverty? Stealing Africa is a political cinema, hinged on how the West's exploitation of Africa, clearly affects the economic atmosphere of the continent. The film is set in Ruschlikon, Switzerland, and Zambia. The African country has the largest copper reserve in Africa, an essential commodity in the

${ }^{11}$ O. Adetunji, Marxist Secular Humanist and Christian Approaches to Moral Education, Ibadan 2001. 
global economy. All of these copper reserves are owned by multinational corporations. The documentary reveals how Zambia, which is representative of Africa, keeps being exploited by the West, even after independence. While humans were not only being recolonized, the environment begins to suffer exploitation and the brunt of capitalism. According to Zambia's Minister for Mines, Zambia is ranked among the bottom 20, in terms of poverty. According to him, the nation is wealthy, yet poor. In fact, despite her enormous wealth of natural resource, Zambia could be categorized in the words of Paul Collier, as one of the bottom billion, caught in... mismanaged dependency on natural resource ${ }^{12}$.

According to a white expatriate, the problem of Zambia is not that of poverty, but it is that of inequality. This position reveals that despite the purported poor situation of the nation, a select few have been able to enrich their pockets with the situation. Africa's natural resources have not reduced poverty on the continent. Most of Africa's leaders have represented the interest of the West. This has been so from colonial times. The West had impoverished the African continent with the help of the African elites. Recall that Ngũgĩ Wa Thiongo captured this in hid novel, Weep Not, Child, where Jacobo, a Kenyan indigene connives with the colonial masters to suppress his people politically and economically. The class division is obvious as inhabitants such as Ngotho are become the wretched of the colonial process.

Despite the boom in the copper enterprise and the rise in the price of the product between 2001 and 2008, the multinational corporations paid nothing substantial in tax to Zambia. The focus of the film is the dubious tax process and environmental destruction by transnational corporations in Africa. Most of these companies thrive on the exploration of natural resources such as crude oil, gold, diamond and so on. In the Niger Delta region of Nigeria, this is not the exception as Chevron, Shell British Petroleum among others engage in the exploration of crude oil. In the case of Why Poverty? Stealing Africa, it is copper, a major resource in Zambia. Zambia is well known for this natural resource.

The political dimension of Biocentrism comes to play in this documentary. There is a display of peaceful protest by women in Zambia. They speak against Mopani Mines Company's (a multinational corporation) activities. Marxist Biocentric Climate Justice approach advocates economic transformation, and at the same time, a disruption of inequality, social inclusion and environmental stability for all. This company's mining enterprise has not only affected the economic spaces, it has also destroyed the natural environment. The women's protest is thus, tailored more towards environmental pollution. Excess spills from Mopani's plant have always contaminated drinking water. The crescendo of this was in 2005 and 2008

12 P. Collier, The Bottom Billion: Why the Poorest Countries Are Failing and What Can Be Done About It, Oxford 2007. 
where more than four hundred inhabitants were hospitalized with complications from vomiting, abdominal pain and so on. This was due to the contamination of water. Reports suggest that such pollution far exceeds national and international standard. Such is a major problem in Africa. The continent has suffered numerous environmental pollutions caused by multinational corporations. In Nigeria's Niger Delta, there have been cases of gas flaring and thousands of cases of oil spillages in places such as Ogoni land, Jesse, Iwhrekreka, Ekakpamre, Ughelli, among others in the Niger Delta, by the oil companies. While the Niger Delta is adjudged the most environmentally devastated place in the world ${ }^{13}$, with the copper exploration trade, Zambia has experienced up to one thousand times more emission of undesirable impurities than required by the World Health Organization. On the other hand, the Chairman of Mopani Mines Company, Emmanuel Mutati refutes the above submission. In his argument:

Mutati: The reference point is the Zambian Environmental Management Agency. We operate within the terms set by the ZEMA. Our licences are within these terms. Hence, I cannot comment on the statement by the NGO. I would suggest that we refer them to ZEMA.

Environmental pollution is political affair where the blame game comes to play. It is obvious from the Chairman's statement that ZEMA is aware of the environmental situation and contended with it. For this, the people seek justice. They want to have a say in the way their natural resources are given out to multinational companies, they desire a reduction in the level of poverty, and they want a mitigation of their environment for a healthy living. In the words of an inhabitant:

Villager: We all wake up in the night and start coughing. The children too. We do not sleep. We just continue coughing when this bad air comes.

The contaminated air mentioned by the above man is as a result of industrialization, a prime mover of the capitalist process. This affirms the submission that increase in industries and the capitalist process has facilitated an upsurge in climate change. Most times, the government connives with the multinational companies to suppress the people economically. Guy Scott, the Vice President of Zambia's comment fully captures the position of Marxist Biocentric Climate Justice theory thus:

Scott: If they are exporting our minerals, the money must come back to Zambia. The current investors should wake up, stand up and be counted and not wait for the government to push them. We do not have time.

${ }_{13}$ B. Nwankwo, The Politics of Conflict Over Oil in the Niger Delta Region of Nigeria: A Review of the Corporate Social Responsibility Strategies of the Oil Companies, "American Journal of Educational Research" 2015, 3 (4). 
Apart from the high rate of unemployment, the inhabitants of Zambia live on less than One US dollar daily. The wealth of the nation is not evenly distributed. According to Cram, "Stealing Africa brought to light how unfair and deceitful multinational corporations can be. The film reveals how a majority of all multinational corporations care about only making themselves richer and making the poor even poorer; how multinational corporations take advantage of other country's assets and unjustly claim the foreign valuable resources as theirs"14. This is also explicated in a wailing villager's complaint that:

Villager: This is very painful because we were not given the opportunity to get the correct value of our assets.

The above statement reveals the dominant spirit of anthropocentrism and individualism blending with capitalistic aspirations of the market, humans have subsequently drifted away from the concerns and situations of the natural ecosystem towards an increasingly privatized world of the in-door ${ }^{15}$.

Einsiedel's documentary film, Virunga, is a conservationist cinema that captures the role of four rangers who risked their lives to protect one of the most spectacular creatures, the great mountain gorillas. In the face of the M23 rebellion in North Kivu, in the Democratic Republic of Congo, in which the government forces and the M23 Movement slugged it out in a duel, four ecocentric and animal friendly rangers felt it imperative to protect the Viruga National Park in the country. This park is Africa's oldest National park. Set in the heart of tropical Africa, and at the epicenter of the brutal civil war, Virunga highlights Biocentrism, climate and animal ethics and justice, as well as class struggle. Precursory to this conservation exercise, numerous wild animals in the Democratic Republic of Congo have died for decades. Virunga National Park at the Democratic Republic of Congo, is home to the majority of the remaining 720 mountain gorillas. The park is one of the richest biological and anthropological places on earth.

The rebel group took over the Virunga park in August 2007. The intense fighting made the rangers pull out of the park at first for refugee camps with their families. However, more than a year later, they return to the park. John Cordega leads the team in search of the gorilla. They find some of the gorillas after hours of search.

Cordega: Every time, you have to stay seven metres from them. When it comes to you, to play with you, you have to retreat seven metres every time.

${ }^{14}$ C. Cram, Stealing Africa: A Review, 2020, https://www.cram.com/essay/The-Argument-OfChristoffer-Guldbrandsens-Stealing-Africa/F394USAY7BQQ [access: 20.02.2021].

${ }^{15}$ R. Baruah, Coloniality of Humans and the Ecology..., op. cit. 
While about thirty two of the gorillas abound before the rangers' flee of the park, in a little more than a year, five new gorillas have been born into the family. Industrialization has always been a major driver of the destruction of the environment. There are industries that use charcoal for production of goods. This search for charcoal for industries and local consumption, threatens the existence of the mountain gorilla as woods are being cut down in the park and processed into charcoal. It is believed that the charcoal trade is worth of 30 million dollars a year. This poses a threat to the lives of the gorilla as five gorillas of the Rugendo family are killed in 2007 by unidentified gunmen as a result of the trade. The killing of the gorillas of the Rugendo family can be controversially compared directly to the killing of Jews and the blindness of the German population under Hitler ${ }^{16}$. An action of this kind has the capacity to impede development. This is because, development should ensure that people and animals are made to live in better conditions ${ }^{17}$.

The international outcry that accompanied the killing of the Rugendo gorillas justifies the film's situation in the Marxist Biocentric Climate Justice theory which advances the complimentarity of man and nature. Non-human animals are part of the environment that must be protected. Virunga is celebrative of socialism over capitalism. It refutes the charcoal trade which enriches a selected few.

Virunga valourizes the environment. The film's long, medium and close up shots of the Virunga National Park characterized with green grass, beautiful fauna and flora, and the aesthetic appeal of the gorillas as they surf the green space with their offspring at their back presents to the audience, the imperative of conservation. Marxist Biocentric Climate Justice theory articulates victory of Biocentrism over anthropocentrism. In the documentary, at the end of the war, the Virunga National Park that housed the mountain gorillas, still remain intact. This is a victory of Biocentrism over Anthropocentrism.

\section{Conclusion}

The connection between climate change and capitalism cannot be disputed. In fact, this is fully replete in Guldbrandsen's Why Poverty? Stealing Africa and Einsiedel's Virunga. These documentary films are grounded in the Marxist Biocentric Climate Justice approach. For global climate justice to be fully achieved, apart from diver-

${ }^{16}$ B. Mandal, Beyond the Dichotomy of Humans and Animals: Situating Ecology in Coetzee's Writings, [in:] S. Kochar, M.A. Khan (eds.), Environmental Postcolonialism: A Literary Response, New York 2021.

${ }^{17}$ C. Okam, Women, Culture and Development: An Examination of the Role of Theatre for Development in the Evaluation of the Millennium Village Project, Pampaida - Nigeria, "Jotams: A Journal of Theatre and Media Studies" 2016, 1 (2). 
sifying from carbon energy into electronic and solar energies, the global focus on the capitalist economic process should be revisited. Also, more African filmmakers should adopt the Marxist Biocentric Climate Justice approach in the ecofilmmaking process since this approach would be an advocacy for environmental protection.

\section{Bibliography}

Adeola T., From Anthropocentric Sinfulness to Bio-centric Gracefulness: Mission to Creation, [in:] T. Babawale, A. Alao (eds.), Global African Spirituality, Social Capital and Self-Reliance in Africa, Lagos 2016.

Adeoye A., Ecotheatre and climate change in Nigeria, [in:] A. Akoh, S. Inegbe (eds.), Arts, Culture and Communication in a Postcolony: A festschrift for Lawrence Olanrele Bamidele, Rochester, United Kingdom 2013.

Adetunji O., Marxist Secular Humanist and Christian Approaches to Moral Education, Ibadan 2001.

Adeyemi L., Literature and climate change: A discourse in eco-criticism, [in:] D. Kuupole, I. Bariki, R. Yennah (eds.), Cross-currents in Language, Literature and Translation: Festschrift for Prof. J.P.A. Ukoyen, Porto-Novo 2012.

Baruah R., Coloniality of Humans and the Ecology: An Eco-critical Reading of Shubhangi Swarup's Latitudes of Longing, [in:] S. Kochar, M.A. Khan (eds.), Environmental Postcolonialism: A Literary Response, New York 2021.

Clark B., Foster J., Marx's Ecology in the 21 $1^{\text {st }}$ Century, "World Review of Economy" 2010, (2).

Collier P., The Bottom Billion: Why the Poorest Countries Are Failing and What Can Be Done About It, Oxford 2007.

Cram C., Stealing Africa: A Review, 2020, https://www.cram.com/essay/The-Argument-Of-Christoffer-Guldbrandsens-Stealing-Africa/F394USAY7BQQ [access: 20.2.2021].

Duggal S., Colonialism, Capitalism, and Nature: A Study of Alex Haley's Roots and Ngũgĩ Wa Thiong'o's Petals of Blood, [in:] S. Kochar, M.A. Khan (eds.), Environmental Postcolonialism: A Literary Response, New York 2021.

Ecocriticism - A Theoretical Perspective, Ecological Concerns in Selected Indian Fiction, 2018.

Ivakhiv A., Green Film Criticism and its Futures, "Interdisciplinary Studies in Literature and Environment" 2008, 15 (2).

Mandal B., Beyond the Dichotomy of Humans and Animals: Situating Ecology in Coetzee's Writings, [in:] S. Kochar, M.A. Khan (eds.), Environmental Postcolonialism: A Literary Response, New York 2021.

Nixon R., Environmentalism and Postcolonialism, [in:] T. Olaniyan, A. Quayson (eds.) African Literature: An Anthology of Criticism and Theory, Oxford, United Kingdom 2007.

Nwankwo B., The Politics of Conflict Over Oil in the Niger Delta Region of Nigeria: A Review of the Corporate Social Responsibility Strategies of the Oil Companies, "American Journal of Educational Research" 2015, 3 (4).

Okam C., Women, Culture and Development: An Examination of the Role of Theatre for Development in the Evaluation of the Millennium Village Project, Pampaida - Nigeria, "Jotams: A Journal of Theatre and Media Studies" 2016, 1 (2).

Wa Thiongo N., Weep Not Child, Nairobi 1969.

Weber M., The Protestant Ethic and the Spirit of Capitalism, New York 1958. 